\title{
CERTIFICATION AS A VIABLE QUALITY ASSURANCE MECHANISM: THEORY AND SUGGESTIVE EVIDENCE
}

\author{
Katarína Svítková \\ Andreas Ortmann
}
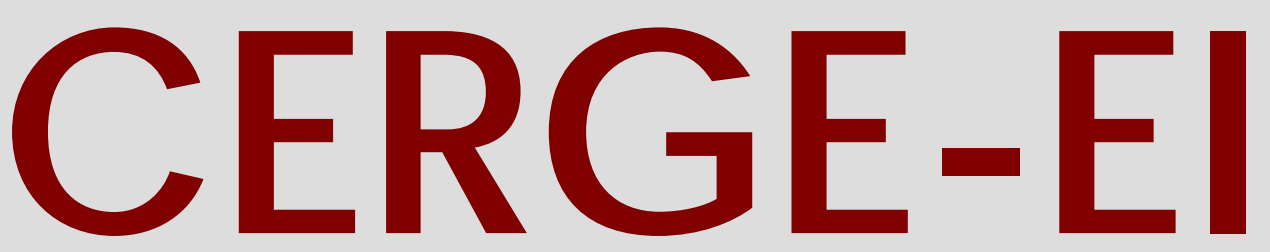

Charles University CenterforEconomic Research and Graduate Education Academy of Sciences of the Czech Republic Ec onomic s Institute 


\title{
Working Paper Series (ISSN 1211-3298)
}

\section{Certification as a Viable Quality Assurance Mechanism: Theory and Suggestive Evidence}

Katarína Svítková Andreas Ortmann

\author{
CERGE-EI \\ Prague, February 2006
}


ISBN 80-7343-083-5 (Univerzita Karlova v Praze, CERGE)

ISBN 80-7344-072-5 (Národohospodářský ústav AV ČR, Praha) 


\title{
Certification as a Viable Quality Assurance Mechanism: Theory and Suggestive Evidence
}

\author{
Katarína Svítková* and Andreas Ortmann \\ CERGE-EI**
}

\begin{abstract}
In this paper we address an asymmetric information problem in the fundraising industry, the fundraising problem. The problem arises from donors' lack of information about the quality of charities that solicit donations. We focus on one particular solution of this problem, certification, where an independent agency provides a costly signal, a certificate, to charities that can use it to signal their 'high' quality. Our model is a signaling game involving three types of player: donors, charities and a certifier. We compare the decisions and impact of two types of certifier: one profit maximizing and one nonprofit. The assumptions of our model are derived from stylized facts that we distilled from certification systems currently existing in the fundraising industries of some European countries. While the current manuscript is meant to inform the real-world design and implementation of such a system in the Czech Republic and other transition economies, our work complements the literature on certification and provides results that are different from those reported up to now.
\end{abstract}

JEL Classification: C72, D21

Keywords: experience goods, quality assurance, certification, self-regulation, enforcement

\footnotetext{
*Email: katarina.svitkova@cerge-ei.cz, andreas.ortmann@cerge-ei.cz

** A joint workplace of the Center for Economic Research and Graduate Education, Charles University, and the Economics Institute of the Academy of Sciences of the Czech Republic.

Address: CERGE-EI, P.O. Box 882, Politických vězňů 7, Prague 1, 11 21, Czech Republic

For insightful questions and comments we thank Marc Bilodeau, Petra Brhlíkova, Dirk Engelmann, Michal Ostatnický, and Richard Steinberg.
} 


\begin{abstract}
Abstrakt
V této práci se zabýváme problémem asymetrické informace v odvětví fundraisingu, tzv. fundraisingovým problémem. Tento problém vzniká kvůli nedostatku informací, které mají dárci o kvalitě organizací, kterým poskytují své dary. My se zaměřujeme na jedno konkrétní řešení tohoto problému, certifikaci, kde existuje nezávislá agentura, která fundraisingovým organizacím poskytuje nákladný signál, certifikát. Ty jej můžou využít k signalizaci jejich „vyšší“ kvality. Model je ve formě hry, zahrnující tři typy hráčů: dárce, fundraisingové organizace a certifikátora. Porovnáváme rozhodnutí a vliv dvou možných typů certifikátora (maximalizující zisk, anebo neziskový certifikátor). Předpoklady modelu jsou odvozeny na základě faktů o několika certifikačních systémech, které existují v Evropě, které stručně sumarizujeme v úvodu práce. Tato studie doplňuje existující literaturu zaobírající se certifikací, uvádí výsledky odlišné od dosavadních, a slouží také jako inspirace reálního, praktického designu certifikačního systému a jeho následné implementace v České republice a jiných tranzitivních ekonomikách.
\end{abstract}




\section{Introduction}

Worldwide, and even within some countries, the fundraising industry is a multi-billion dollar business (Giving USA, 2004; Salamon et al., 1999). Its basic function is to persuade potential donors to give generously to nonprofits to finance their operations. This may happen directly when the nonprofit's fundraising operation is in-house, or indirectly when the fundraising operation is a foundation that mediates the process of giving by soliciting funds and distributing them to appropriate nonprofits. In the following, we do not concern ourselves with the specifics of the channels through which donations flow from donors to the entities that spend them. Rather, we are interested in understanding the problem of asymmetric information, i.e., the principal-agent problem, between donors and the charities that are the recipients of their generosity. Below we refer to this problem as the fundraising problem: Donors often know little about the entities that they have decided to give money to (e.g., the recent tsunami relief efforts), thus opening the door for potential abuses. ${ }^{1}$

The severity of the fundraising problem can be mitigated by the non-distribution constraint imposed by law or regulation on organizations in the nonprofit sector. It has been argued that this constraint, if enforced effectively, significantly decreases the incentives of nonprofit entrepreneurs to abuse the trust of donors and that it increases the probability that the donated funds are spent effectively and efficiently (e.g., Hansmann, 1980). Unfortunately, enforcement of the constraint is often wanting (e.g., Ortmann and Schlesinger, 2003). The fundraising problem can also be mitigated by charities signaling their quality by having reputable members on board (Handy, 1995), or by engaging in sequential fundraising (Vesterlund, 2003), so that small donors believe that the initial big donor had better access to information and chose to support an organization of high quality. Another signal of high quality may be if the organization is contracted by the government

\footnotetext{
${ }^{1}$ Some argue that the severity of the problem depends on the donor's size, the argument being that a large donor surely will give large amounts only if she can control the outcome. There is something to the argument that in principle a donor could send her own "investigators" to evaluate whether the charity spent the donation in line with its promises. But we typically see this rarely, which suggests that it is costly, and/or that there are economies of scale in assessing charities.
} 
(e.g., Gronbjerg, 1997), as the government is expected to evaluate the organizations it hires, or membership in a well-recognized group, say United Way in the U.S.A. (Rose-Ackerman, 1980), which, one hopes, will screen its members.

Despite these mechanisms numerous well-documented scandals (e.g., Ortmann and Schlesinger, 2003; Gibelman and Gelman, 2004; Panel on the Nonprofit Sector, 2005; Bullain and Marshall, 2005) emphasize the continued existence of the fundraising problem and call for additional action. Different countries have chosen starkly diverging institutional solutions. In the U.S.A., for example, the interested parties have relied mostly on Form 990 which the Internal Revenue Service requires all nonprofits (including foundations) above a given revenue threshold to fill out. This public document has become the key input in a new decentralized monitoring system called GuideStar that allows interested parties to search through millions of IRS 990 forms, and to do so (in return for a fee) in a highly structured search environment. The problem with the IRS 990 Form and GuideStar is that all the data are self-reported and, in addition, not well standardized (Froelich, Knoepfle, and Pollak, 2000), leaving considerable room for abuse. In contrast, especially in Europe, the interested parties have relied on various forms of certification systems whose common denominator is that fundraising entities submit voluntarily, and for a fee, to the investigations of an independent agency that will issue a seal of approval, or certificate, assuring donors that the applicant has met some standard of quality.

Currently certification systems in the fundraising industry exist in countries such as Germany, the Netherlands, Switzerland, Sweden, Austria, and the U.S.A./Canada (e.g., Guet, 2002; Ortmann, Svitkova, and Krnacova, 2005), although they do so in a surprising variety. Notably, certification systems do not presently exist in transition and developing countries. This may be for the simple reason that the nonprofit sector is not developed enough to warrant quality assurance mechanisms. Some have argued that the typically weaker enforcement of laws and regulations makes certification not a viable solution in such environments. We claim, in contrast, that certification systems are particularly suited 
to benefit society if the laws and regulations are enforced weakly, partially because under such circumstances other mechanisms fail to operate.

Be that as it may, in light of the existing, starkly diverging realizations that we find in Europe, and in light of the fact that some attempts to start certification mechanisms (such as the English one; see Ortmann, Svitkova, and Krnacova, 2005) have been prominent failures and, lastly, in light of the growing importance of the nonprofit sector in transition and developing countries (Salamon et al., 1999; Brhlikova, 2004; Svitkova, 2004), pondering the incentive properties of certification mechanisms under those circumstances seems worthwhile. Indeed, our interest in the topic was triggered by the question of whether, and if, what kind of certification system would be viable in the transition economy that we live in.

We note that, even though here we use the fundraising problem as our running example, our theoretical considerations below apply to all problems of asymmetric information of a similar make: To the extent that commercial nonprofits, or even for-profits, produce experience and credence products (goods or services), they face, at least in principle, the same kind of problems that fundraisers face.

The literature that is most closely related to our work is theoretical research on intermediaries whose task is to mitigate the asymmetric information problem in product markets (Strausz, 2005; Peyrache and Quesada, 2004, 2002; Lizzeri, 1999; Biglaiser, 1993; Biglaiser and Friedman, 1994) or labor markets (Spence, 1973). None of these papers, however, capture the specific features of the fundraising industry, namely the nonprofit status of the certification agency itself or the specific welfare consequences of trustworthiness of the individual nonprofits and the nonprofit sector as a whole. In fact, some of these models (e.g., Lizzeri, 1999; Peyrache and Quesada, 2002) lead to rather counterintuitive and undesirable results, such as the certification agency capturing all surplus. 
The second section of the manuscript details stylized facts about the certification systems that we currently observe. The third section lists assumptions for the model based on the observed facts and describes the setup and timing of the basic and extended games. The fourth section provides results, while the fifth lists future extensions, policy implications and a conclusion.

\section{Stylized facts}

The aim of this study is to build a model that allows us to study the fundraising problem and the viability of a particular solution to this problem, certification. Towards that goal we first enumerate the stylized facts that a more institutionally-oriented companion study of such certification systems has produced (Ortmann, Svitkova, and Krnacova, 2005; see also Guet, 2002). ${ }^{2}$ Since our basic model is a signaling game, we use game-theoretic terminology even in the description of the stylized facts. As mentioned, we examine the fundraising market focusing on the asymmetric information problem between charities and donors, and the role of a certifier.

F1. [Charities and their goals] Charities (fundraising organizations) raise funds, or donations, for various charitable purposes. Their aim is to collect as many donations as possible. Toward that end they typically make promises about how they will spend the funds raised.

F2. [Quality of charities] The charities differ in quality as measured by administrative costs, quality of project management, the fraction of donations that reaches those in need, and the quality of the projects offered.

\footnotetext{
${ }^{2}$ The facts enumerated in this section provide the 'suggestive evidence' that certification may help to solve the fundraising problem. We call it suggestive as it is based on a small set of real-life cases that have some commonalities but also differ in important aspects such as whether they farm out the substance of their evaluations or do them in-house, the kind of charities that they admit as candidates, and their reliance on public subsidies.
} 
F3. [Observability of the quality of charities] The quality of charities is typically not observed by donors, ${ }^{3}$ i.e., the fundraising problem arises.

F4. [Donors and their goals, demand] Donors give donations to charities. Their motivations can be rather diverse. ${ }^{4}$ But, importantly for certification, a significant number of donors appreciate quality - if there is a certificate, donors who care about quality shift their giving to the certified charities only. Moreover, donors increase their giving to certified charities, and they do so increasingly with higher quality (Bekkers, 2003).

F5. [Certifier and his goal] The certifier provides a seal of approval, or certificate, that guarantees that fundraising organizations that receive it do in fact meet some minimal quality requirement. ${ }^{5}$ A certifier, too, may be motivated by various objectives, but all certifiers of charitable organizations that we observe (Guet, 2002) are nonprofit organizations. $^{6}$

F6. [Certification is a costly signal; the two components of the cost] The certificate is a costly signal for two reasons: First, compliance with the quality standard (possibly misrepresentation of the true quality) is more difficult/expensive for charities of lower quality (costs related to the process of certification, such as administrative costs, preparation of documents, are higher for charities that are of lower quality). Second,

\footnotetext{
${ }^{3}$ Empirically, there are always charities that have established reputations on their own, or are able to signal their quality using other tools (see the Introduction), and do not seem to need the certifier, especially initially, to guarantee that they meet some minimal quality. Interestingly, experience has shown that many of these charities do end up asking for certification (Ortmann, Svitkova, and Krnacova, 2005). The reason for this will be become clear in the discussion of our model.

${ }^{4}$ A number of studies suggest that donors differ in their motives to give (Andreoni, 1990; Glazer and Konrad, 1996; Harbaugh, 1998a, 1998b); it is, however, not the aim of the current paper to analyze these motives further.

${ }^{5}$ It is important to realize that a certifier is different from an auditor, the main difference being the extent of the requirements on the charity's operation. Certifiers do check the financial operations of charities, but they also check many other aspects such as governance or management. For more details, see Ortmann, Svitkova, and Krnacova (2005).

${ }^{6}$ However, this is true only for certifiers of charitable organizations. Other seal-of-approval systems (e.g., ISO) typically have profit-maximizing certifiers.
} 
charities have to pay fees (initial fees, annual fees, recertification fees) set by the certifier. These fees typically vary with the size of the evaluated fundraising organization. ${ }^{7}$

F7. [Cost of detection technology] Detection is costly, and it is not necessarily without mistakes. The certifier chooses among detection technologies which differ in costs and produce different probabilities of detection (e.g., the Dutch-German model on the one hand and the Austrian model on the other hand; see Ortmann, Svitkova, and Krnacova, 2005).

F8. [Disclosure rules] The certifier announces only whether the organization has obtained a certificate or not - typically he does not disclose additional information about the quality of the certified organizations, nor does he rank the organizations. ${ }^{8}$

3. Model: Assumptions and timing

We now map the stylized facts onto assumptions that lay the foundations for our model. The game is sequential and involves three types of players: charities, donors, and a certifier. We assume that charities and donors are of measure 1 . The certifier is a single player. The timing of the game is described below.

A1. [Charities and their goals, based on F1] We assume charities (fundraising organizations) maximize the amount of net revenues. We assume that the only fundraising costs are the costs of certification.

\footnotetext{
${ }^{7}$ This is true for all the cases considered in Ortmann, Svitkova, and Krnacova, 2005: Austria, Germany, the Netherlands, and Switzerland. Certification is free in Sweden (the system is supported by state subsidies); the charities must pay the costs of investigation only in case of special inquiry. The internal costs, however, are incurred in all cases.

${ }^{8}$ We note that other disclosure rules have been observed in other industries. For example, JD Power ranks brands of cars according to their quality (Peyrache and Quesada, 2002). We conjecture that the easier comparability of output in the car industry might drive that result. The easier comparability of output is likely to induce a differentiated demand response. Because of the more difficult comparability of the output of fundraisers, such a differentiated demand response seems not possible.
} 
A2. [Quality of charities, based on F2] The quality (type) of the charity is represented by $t$; we assume $t$ is distributed according to a uniform distribution on the unit interval, $\mathrm{F}(\mathrm{t}) \sim$ $\mathrm{U}[0,1]$. Higher $t$ represents higher quality, which can be interpreted, for example, as a higher fraction of donations reaching their purpose but also higher quality of the project pursued. For the sake of simplicity, quality is assumed to be one-dimensional and fixed for now. ${ }^{9}$

A3. [Observability of the quality of charities, based on F3] Donors do not observe $t$, the quality of individual charities. They observe only the cumulative distribution function, $F(t)$.

A4. [Donors and their goals, demand, based on F4] There are two types of donors. First, there are uninformed donors, who do not learn about certification. ${ }^{10}$ Their behavior is the same regardless of the existence and behavior of the certifier. Therefore we do not discuss them further, as their existence does not qualitatively affect the results (but their existence is crucial to ensure the survival of non-certified charities). Second, there are informed donors, who learn about certification. These donors adjust their behavior incorporating the additional information provided by the certifier. From here on we focus on the behavior of the informed donors only, and, for economy of notation, refer to them as donors.

If there is no certifier in the market (no additional information is available), then donors give according to the quality of the average organization, $E[t]$. If there is a certifier in the market, donors learn about him, and the standard the certificate ensures, and change their behavior: ${ }^{11}$ they shift all giving to certified charities only and increase their giving in appreciation of the higher quality of the certified charities. Donors adjust their donations

\footnotetext{
${ }^{9}$ We realize that a certification mechanism may well affect, and hopefully does affect, the distribution of types. But the evidence in the organization and management literature suggests that organizations, and their corporate cultures, are rather difficult to build or turn around. In addition, a model endogenizing the distribution of types would be more complex and shift the focus towards an analysis of the evolution of the fundraising industry. That is an interesting topic, but is not a topic of interest in the present context.

${ }^{10}$ These donors do not care about the quality of the organizations they support; they give for some other reason, e.g., the warm glow.

${ }^{11}$ In this work we do not explicitly model the utility function of donors, however, it is straightforward to extend the model in this direction.
} 
according to the fraction of charities with the certificate, $f_{C}$; we assume a giving function $\mathrm{E}[t \mid t>s] * f_{C}{ }^{12}$ The donations that a certified charity expects are therefore $E\left[t \mid t>_{S}\right]$, reaching the maximum at the highest standard, $s=1$. The donations that a non-certified charity expects are 0 .

A5. [Certifier and his goal, based on F5] The certifier provides a certificate that guarantees that charities that have obtained it meet a minimal quality requirement, the standard $s$. We assume the certifier maximizes one of two objective functions: profit (benchmark case), or 'Money to Africa' (nonprofit certifier), which is, for now, our measure of welfare, and is explained in more detail later.

A6. [Certification as a costly signal; the two components of cost, based on F6]

Charities that apply for certification incur two types of costs of certification, internal costs and the fee.

The internal costs, i.e., the costs of the administrative procedures related to certification, are incurred if the organization applies for the certificate (necessary condition). We assume they take one of these two forms:

A6i. $c(t), c^{\prime}(t)<0$, a decreasing function of $t$. This form of the cost function is used for our basic model that will help us fix the basic ideas of certification.

A6ii. $c(t, s), c_{t}(t, s)<0, c_{s}(t, s)>0$, is a function of both quality, $t$, and standard, $s$. We assume that $c(t, s)$ decreases in quality and increases in standard: if the standard is low the costs of preparing for certification are also low, independent of the quality of the organization; in contrast, if the standard is high then preparing for

\footnotetext{
${ }^{12} \mathrm{We}$ assume that the number of charities affects giving, e.g., by increased advertising (higher visibility of the sector, or of the cause addressed).
} 
certification is costly, particularly for those organizations that do not meet the standard and that therefore might have to misrepresent themselves. ${ }^{13}$

The fee for certification is denoted $P$. For the sake of simplicity, we assume $P$ constant, i.e., we assume that all charities in the market are of the same size, or that the large organizations are aggregates of several small ones. ${ }^{14}$

A7. [Costs of detection technology, based on F7] The certifier is not able to assess organizations without mistakes. The detection technology is not free; its costs are denoted $c_{C F}(\varepsilon)$, where the subscript denotes certifier and $\varepsilon$ denotes the 'range' of mistakes. We assume detection technology to be uniquely determined by $\varepsilon$. A certifier with detection technology $\varepsilon$ observes $t_{o}$ as the quality of a charity of type $t, t_{o} \in(t-\varepsilon, t+\varepsilon) ; t_{o}$ is distributed uniformly over the interval $(t-\varepsilon, t+\varepsilon)$.

We assume $c_{C F}(\varepsilon)=0$ for $\varepsilon=1 / 2$, i.e., even the worst technology allows the certifier to perfectly identify charities at a distance $1 / 2$ from the standard; however, as $\varepsilon \rightarrow 0$ better technologies are required at an ever increasing cost, $c_{C F}{ }^{\prime}(\varepsilon)<0, c_{C F}{ }^{\prime}(\varepsilon)>0$. Thus, $c_{C F}(\varepsilon)$ $\rightarrow \infty$, and perfect detection (of all charities) is not possible.

A8. [Disclosure rules, based on F8] We assume that the certifier announces only whether the organization has obtained a certificate or not-he does not disclose additional information about the quality of the certified organizations, nor does he rank the organizations. ${ }^{15}$

\footnotetext{
${ }^{13}$ Throughout this study we work with costs that are linear both in $t$ and $s$; however, it should be possible to consider functions that are convex in both $t$ and $s$, with negative cross-derivative (representing opposite effects of $t$ and $s$ - the negative impact of $t$ on costs may be mitigated by increasing $s$ ). The robustness of our results to different specifications of our cost functions, or demand shifts induced by certificates, are obviously important topics for future research.

${ }^{14}$ Indeed, several of the companies studied in Ortmann, Svitkova, and Krnacova (2005) charge an annual fee depending on the size of revenues, typically a per mil of revenues (e.g., Swiss certifier ZEWO). All certifiers studied in more detail in Ortmann, Svitkova, and Krnacova (2005) have similar schemes.

${ }^{15}$ This assumption is based on what we observe in reality. Lizzeri (1999) shows that a profit-maximizing certifier chooses no disclosure (among various possible disclosure rules) to maximize his profit; we realize it
} 
The relation of the following assumptions to reality is not that straightforward, but they are needed to simplify the model.

A9. [What donors observe] Donors observe the standard, $s$, and certificates only (consequently, the number of certified organizations). Specifically, they do not observe any of the costs, internal costs, fee, or costs of technology. Donors, for now, believe that the certifier is committed to being honest. ${ }^{16}$

A10. [Commitment of the certifier] We assume that the certifier is honest and does not misrepresent the standard or quality of the certified organizations. This argument can be rationalized along the lines of Klein and Leffler (1981).

We proceed with the formalization of the full game. The timing of the game is as follows:

1. The charity learns its type, $t$, and the internal cost function, $c(t, s)$.

2. The certifier sets standard, $s$, fee, $P$, and detection technology, $\varepsilon$.

3. The charity observes the conditions of certification, $s, P$, and $\varepsilon$, and decides whether to apply for certification or not (based on the probability of receiving the certificate, $p$, and the internal costs $c(t, s))$ in order to maximize the net revenues (the expected donations less costs of certification).

4. The certifier examines the charities that apply for certification and awards certificates to those that pass his standard (deciding based on the type observed, $t_{o}$, awarding certificate with $p$ : making a mistake with probability $1-p$ for types above $s$, and $p$ for types below $s$ ).

\footnotetext{
is important to understand why a nonprofit certifier chooses the same disclosure rule. We will address this question in future research.

${ }^{16}$ An alternative assumption may be that the donors are able to observe the conditions of certification themselves by controlling the work of the certifier. Such a scenario we do not observe empirically and, in any case, such a scenario would not qualitatively affect our results.
} 
5. Donors adjust their donations to the standard, $s$, and to whether a charity is certified or not.

We solve the game by backward induction. Our aim is to determine a pure-strategy sequential equilibrium separating good and bad types (types above and below a given standard).

We solve a simplified game and a full game in two stages. In the simplified game we omit the decision problem of the certifier and assume perfect detection; we solve it to fix ideas and illustrate the relation to Spence (1973). The full game is solved in two stages; in the first stage we solve for the optimal decision of the charity. There, the certifier is simply a mechanistic provider of the certificate. In the second stage we solve for the optimal decision of the certifier. The full game is solved for two cost configurations and two objective functions of the certifier.

\section{Model: Results}

\subsection{Simplified game}

We first solve the simplified game, a signaling game somewhat similar to the one in Spence (1973). ${ }^{17}$ We assume for now that the internal costs are a function of type $t$ only, $c(t)$ (A6i), and that the certifier has a solely mechanistic role: he awards the certificate to all charities that apply and incur the costs necessary $(P$ and $c(t))$, i.e., there is no further examination or mistakes. The certifier is a provider of the certificate, he gives charities an opportunity to distinguish themselves. Because of the costs that need to be incurred only charities for which it pays off to apply do apply.

\footnotetext{
${ }^{17}$ In the Spence game educational institutions give workers (charities in our model) the opportunity to signal their quality to their potential employers (donors). Separation occurs because learning is easier for workers of higher quality (certification is cheaper for higher quality charities). However, there are important distinctions: we examine what the optimal behavior of the certifier (school) is under two different organizational schemes, what the effect of mistakes in evaluation is, and so on.
} 
If a separating equilibrium exists, the decision of a charity to apply for certification satisfies the incentive compatibility constraints (ICCs) in equation [1]; i.e., charities of quality above (below) standard are better off (not) asking for certification:

$d_{C}-P-c(t)<d_{N C} \quad$ for $t<s$

$d_{C}-P-c(t)>d_{N C} \quad$ for $t>s$.

Where $d_{C}$ is the expected donation to a certified charity, $E[t \mid t>s]$, the fraction of charities with a certificate is $1-s ; d_{N C}$ is the expected donation to a non-certified charity (by A4 we assume that it is 0$), P$ is the fee paid for certification, and $c(t)$ are the internal costs of charity of quality $t$.

We assume separation occurs at the standard, $s$. If a separating equilibrium exists, there must exist a standard $s^{*}$ satisfying both ICCs with equality such that:

$d_{C}-d_{N C}=d_{C}=c\left(s^{*}\right)+P$.

In the separating equilibrium types with $t>s^{*}$ (which from here on we shall call 'good charities') ask for certification, pay the separating fee, $P^{*}=c\left(s^{*}\right)-\left(d_{C}\left(s^{*}\right)-d_{N C}\left(s^{*}\right)\right)$, incur $c(t)$, obtain the certificate, and receive a donation $d_{C}\left(s^{*}\right)$. Types with $t<s^{*}$ (which from here on we shall call 'bad charities') do not apply and do not receive donations. ${ }^{18}$

From equation [2] we see that for the type at the separating equilibrium, $s^{*}$, the costs of certification (internal costs and fee) are equal to the increase in donations due to certification. Thus, the expected profit of the type at the separating equilibrium, $s^{*}$, is 0 , types above $s^{*}$ are left with a surplus because their internal costs are lower. The increase in donations is known: with giving functions as defined by A4 and A2 (uniform distribution), 
and no mistakes in detection, the difference in donations is $E[t \mid t>s]=(1+s) / 2$, a function increasing in standard. The solution of $c\left(s^{*}\right)+P=d_{C}-d_{N C}$ depends on $c\left(s^{*}\right)$, the shape of the cost function. Assuming a linear cost function, $c(t)=1-t$, we get the unique separating fee as an increasing function of the standard, as depicted in Figure $1 .{ }^{19}$ The identified solutions all determine a one-to-one relationship between a standard and the fee that needs to be charged to induce separation at this standard.

Figure 1: Separating fee, $P^{*}$, as a function of standard $s$ (for $\left.c(t)=1-t\right)$

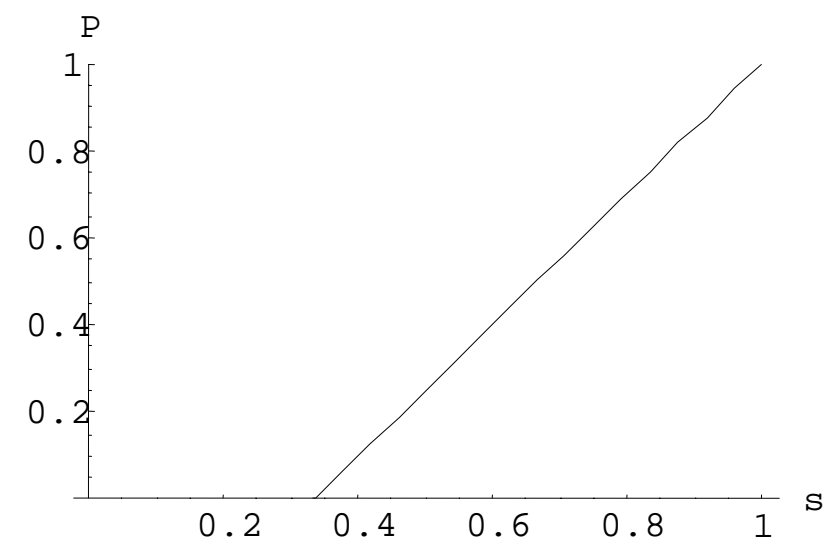

Charging a higher fee leads to separation at a higher standard. Note that even charging no fee at all induces separation at a positive standard $(s=1 / 3)$. This is intuitive: for types below this threshold, the payoff from certification is too low to entice them to participate, i.e., the internal costs are too high to allow participation (in consequence of A6i). In terms of the rearranged condition, $c(t)>d_{C}-d_{N C}$ if $P=0$. This also means that a pooling equilibrium (in which all charities have the certificate) does not exist.

In the following sections we solve the full game: We relax the simplifying assumptions of the basic game by allowing for the certifier to make mistakes, and by introducing the certifier's optimization problem. We solve the game in two stages, in the first one (Sections

\footnotetext{
${ }^{18}$ The equilibrium conditions illustrate why some of the charities with established reputations that rejected certification initially end up asking for it later - the expected revenue outweighs the cost.

${ }^{19}$ All computations and figures in this paper were done in Mathematica v. 4.1.
} 
4.2 and 4.3) we continue to assume that the certifier is a mechanistic provider of the certificate while we study the optimal decision of a charity (whether to apply for certification or not). In the second stage (Section 4.4) we solve for the optimal decision of the certifier.

We solve the first stage of the game for two cases. In the first case (Section 4.2) we assume that - mistakes notwithstanding - separation still occurs at the standard, $s$. As there are no bad charities applying, the detection technology plays only a minor role in that it might exclude (falsely) good charities. In the second case (Section 4.3) we assume that separation occurs below the standard, $s$. As now there are bad charities applying, the detection technology becomes more important in that-while it still might exclude (falsely) good charities - it will now detect some of the bad charities. How many of these it detects is a function of the detection technology assumed. Thus, the second case is more general: it expands the set of schemes the certifier can choose from (a problem we address in the second stage of the game, Section 4.4), and allows us to study the trade-off between the fee for certification, $P$, and the detection technology, $\varepsilon$, the certifier's key tools to prevent bad charities from getting the certificate.

\subsection{Full game, first stage, 'bad' charities do not apply (case 1)}

We now relax the assumptions of the simplified basic game: specifically, we assume that the internal costs are a function of both type, $t$, and standard, $s$ (A6ii); we work with the simple specification $c(t, s)=(1-t) s$. We also assume that the certifier owns a detection technology. The quality of the detection technology, $\varepsilon$, together with the standard and the type of the charity determine the probability, $p(s, t, \varepsilon)$, that a charity that applies for certification will obtain the certificate. Even though the certifier realizes that he might make a mistake, i.e., $t_{o} \in(t-\varepsilon, t+\varepsilon)$ where $t_{o}$ is the observed type of the charity under consideration, he awards the certificate if $t_{o}$ is above $s$. Under the maintained assumption of a uniform distribution of $t_{o}(\mathrm{~A} 7), p(s, t, \varepsilon)=\mathrm{p}\left[t_{o}>s\right]=1 / 2+(t-s) / 2 \varepsilon$. Note that the charity at the standard $(t=s)$ is awarded the certificate with probability $1 / 2=1 / 2+(t-s) / 2 \varepsilon$. Note also 
that probability of being awarded the certificate is $>1 / 2$ for charities of type $t>s$, and $<1 / 2$ for those of type $t<s$.

For now, we assume (as in the simplified game) that the separating equilibrium occurs at the standard, $s$. For a separating equilibrium to exist, the decision of a charity to apply for certification has to satisfy the incentive compatibility constraints (ICCs) summarized below.

$$
\begin{aligned}
& p(s, t, \varepsilon) d_{C}+(1-p(s, t, \varepsilon)) d_{N C}-P-c(t, s)<d_{N C} \quad \text { for } t<s ; \quad \text { ICC for the bad types; } \\
& p(s, t, \varepsilon) d_{C}+(1-p(s, t, \varepsilon)) d_{N C}-P-c(t, s)>d_{N C} \quad \text { for } t>s ; \quad \text { ICC for the good types. } \\
& \Leftrightarrow \\
& p(s, t, \varepsilon) d_{C}-P-c(t, s)<0 \quad \text { for } t<s \\
& p(s, t, \varepsilon) d_{C}-P-c(t, s)>0 \quad \text { for } t>s .
\end{aligned}
$$

Recall that $p(t, s, \varepsilon)$ is the probability that a charity of type $t$ receives the certificate and that the expected donations to non-certified charities are nil by A4, and therefore do not appear in the rearranged conditions [3]. Strictly speaking, $d_{C}=d_{C}(s)$ and $d_{N C}=d_{N C}(s)$; we omit the argument to simplify the notation. Note that [3] is inequality [1], modified by $p(t, s, \varepsilon)$.

From the re-arranged ICCs [3] we see that the expected revenue of good types is greater than the costs, i.e., some good types have, ex ante, the incentive to apply even though ex post they may fall through the cracks. In contrast, the bad types receive donations only in case of a mistake (induced by the imperfect detection technology) but the expected value of these donations is swamped by the internal costs, $c(t, s)$, and the external costs, $P$, both of which are bounded away from zero. Because the expected value of these donations is less than the costs that would have to be incurred, the bad types will not apply in the first place. $^{20}$

\footnotetext{
${ }^{20}$ This assumes that an applicant will have to pay the fee, $P$. (They will have to pay the internal costs anyway.) Indeed, as the example of German certification agency DZI demonstrates, unsuccessful applicants do have to pay the application fee. This affects nearly one third of the applicants, with these costs becoming sunk for about one fifth of the applicants. Qualitatively, this fact strengthens the incentives of applicants to
} 
To identify the solution we have to look for the type that would induce separation at $s, t=s$. As we already established, the detection probability-independent of the certifier's detection technology (A7) - is $1 / 2$ if $t=s$. In equilibrium both ICCs have to be satisfied with equality:

$1 / 2 d_{C}\left(s^{*}\right)=P+c\left(s^{*}, s^{*}\right)$

As in the simplified game (from condition [2]), we obtain the fee necessary to induce separation at $s, P^{*}(s)$, from condition [4]. Figure 2 illustrates.

Figure 2: Separating fee $P^{*}$ as a function of standard $s($ for $c(t, s)=(1-t) s)$

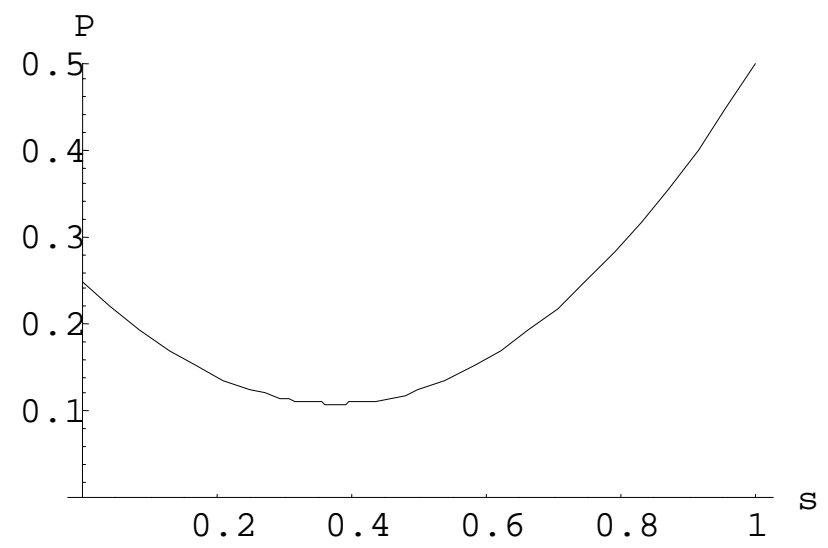

The separating fee differs from the one in the simplified game; specifically, it is positive for all values the standard might take, i.e., there does not exist a threshold so that charities below it would never apply for certification. This result follows because the internal cost function that we assume here decreases in the standard. If the decrease in the internal cost is larger than the decrease in the expected donations (as with our specification of internal cost

reveal their type. If unsuccessful applicants would not have to pay the application fee, the argument in the text would be affected only quantitatively but not qualitatively, as long as the internal costs would swamp the expected value of getting donations that one does not deserve. 
and giving functions) the fee, $P^{*}$, needs to increase as the standard decreases to prevent the bad charities from applying.

\subsection{Full game, first stage, 'bad' charities apply (case 2)}

We maintain the assumptions from case 1 (internal costs, $c(t, s)$, detection technology, $\varepsilon$ ) with the following exception: we now allow for separation to occur below the standard, $s$. Thus, even if the standard, $s$, is announced to the public and the certifier requires charities to meet it, the fee, $P$, will be below the separating fee identified in case $1, P^{*}(s)$. This gives some bad types an incentive to apply for certification that did not do so before. Whether bad charities do obtain the certificate depends on the detection technology, $\varepsilon$. We analyze this case because, as we will see in the second stage in Section 4.4, the certifier may indeed be motivated to allow some bad charities to apply for certification (although he will prevent some of them to get the certificate by way of his detection technology).

Such behavior might seem to be a violation of the assumption that the certifier is honest (A10). The certifier, however, does not intentionally deceive donors by handing out the certificate to bad charities. Rather, he attempts to keep the bad charities out through his detection technology instead of the high fee, $P$. We therefore maintain that donors consider the certifier honest and give according to the standard, $s,(\mathrm{~A} 9)$.

Let us denote the new separating point $T$. The ICCs ensuring separation at $T$ are then:

$$
\begin{array}{ll}
p(s, t, \varepsilon) d_{C}<P+c(t, s) & \text { for } t<T ; \\
p(s, t, \varepsilon) d_{C}>P+c(t, s) & \text { for } s>t>T .
\end{array}
$$

Note that both the donations, $d_{C}$, and the internal costs, $c(t, s)$, require that charities meet the standard $s$. The probability of being awarded the certificate is below $1 / 2$ in both inequalities because all the types below the standard are awarded the certificate by mistake. 
To identify the solution we have to look for the type - now a function of $s, P$, and $\varepsilon$ - that would induce separation at $T, t=T$. In equilibrium both ICCs have to be satisfied with equality. Figure 3 illustrates. (It is necessary to read the figure with caution as we consider only points where $T \leq s.)^{21}$

Figure 3: Separating type, $T(s, P, \varepsilon), \varepsilon=.4$

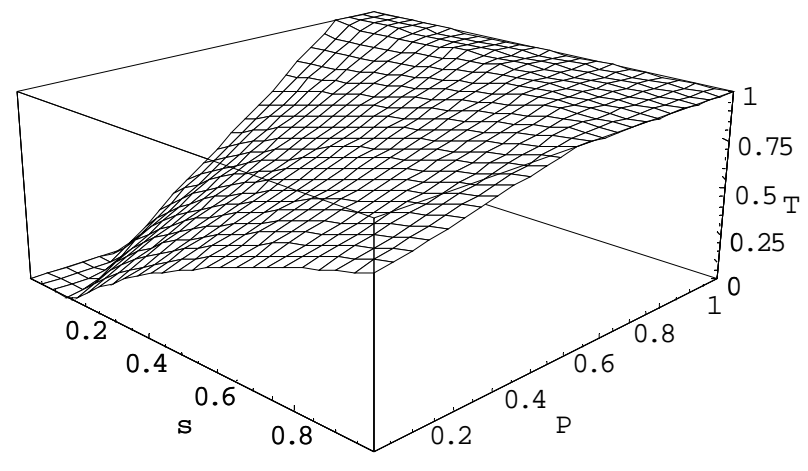

We observe that the separating equilibrium does not exist for high fees as these effectively ban charities of all types from applying for certification; the result is in line with the result obtained in Section 4.2, where .5 was the highest price still allowing separation. $T$ increases in the standard $s$ : ceteris paribus, a higher standard means higher expected donations, motivating charities of lower quality (from the set of bad charities) to apply. However, a higher standard also means higher internal costs imposed on charities, and a lower probability of being awarded the certificate (a charity of type $t$ is 'farther away' from the standard). These negative effects are stronger than the increase in the expected donations, thus, the separating point increases. As expected, $T$ increases in the fee, $P$, because a higher fee translates one-to-one to higher costs making certification pay only for charities of higher quality. $T$ decreases in detection technology $\varepsilon,{ }^{22}$ as better detection decreases bad charities' probability of getting the certificate, i.e., they have no incentive to apply in the first place.

\footnotetext{
${ }^{21}$ Also, the figure is slightly biased because we computed the fraction of certified charities with an assumption $s+\varepsilon>1$, which does not hold for $s<.6$ (as $\varepsilon$ is assumed to be .4).

${ }^{22} \mathrm{We}$ cannot observe this in the figure, as technology is fixed there.
} 
These results spell out a trade-off for the certifier: he can keep bad charities out either by charging them a high fee (increase $T$ by increasing $P$ up to $s$, the limit case studied in Section 4.2), or by letting them apply and rejecting them through his detection technology (increase $T$ by decreasing $\varepsilon$, however, as perfect detection is not available, $T$ would be below $s$ if the fee were not adjusted). How the certifier addresses this trade-off, and how he chooses an optimal certification design, is discussed in the following section.

\subsection{Full game, second stage}

We now complete the solution of the full game by identifying the certifier's optimal choice of $s, P$, and $\varepsilon$. We assume that the certifier has one of two objective functions that we label profit-maximization and 'Money to Africa', or nonprofit. Guided by his objective function, the certifier may now choose a separating equilibrium at the standard, $s$, or below. He does so by choosing simultaneously the technology $\varepsilon$, the standard $s$, and the fee $P$ (that is, either $P^{*}$ identified in Section 4.2 or any positive $P$ below $P^{*}$ (Section 4.3)). He also considers the pooling equilibrium where all charities are awarded the certificate.

We call the certifier that maximizes profit the for-profit certifier and discuss the results in Section 4.4.A; we call the certifier that maximizes 'Money to Africa' the nonprofit certifier and discuss the results in 4.4.B. 'Money to Africa', i.e., the amount of donations that reaches those in need less administrative costs broadly construed, is our measure of the welfare of society. Both cases are analyzed for two parameterizations of the certifier's cost function $c_{C F}(\varepsilon),{ }^{23}$ high and low. The objective functions represent polar opposites. Thus, our solutions provide benchmarks for other organizations that may exist in the market. Needless to say, our results below depend on the particular functional specification; the robustness of our results is subject to further research. 


\section{A.) Profit-maximization}

The certifier maximizes:

$\underset{s, P, \varepsilon}{\operatorname{Max}}(1-T) P-c_{C F}(\varepsilon)$.

The first term denotes the certifier's revenue from certification, and the second term denotes the costs of his technology. $s, P, \varepsilon$ are the choice variables of the certifier that induce separation at $T ; P$ is below or equal to the fee $P^{*}(s)$, inducing separation at $s$. While the certifier maximizes his profit choosing all three variables simultaneously, we discuss the individual choices in turn.

The optimal fee for certification is identified as the fee that balances the marginal cost of increasing the fee (decreased income due to decreased participation) and the marginal revenue (increased income due to an increase in the fee paid by all paying participants).

With the specifications used (especially for the internal cost and the giving functions), marginal revenue is above marginal cost for all fees below $P^{*}$ leading to a corner solution in which the certifier charges the highest fee possible, $P=P^{*}(s)$. This implies that no bad charities apply for certification.

The optimal investment in detection technology is zero, as such investment affects profits only negatively as a direct expense, $c_{C F}(\varepsilon)$. In addition, since the certifier charges the maximum possible fee, $P^{*}(s)$, and separation occurs at $s$, there are no bad charities applying for certification. Thus, better technology only decreases the number of good charities falling through the cracks. As these charities have already paid their fee (increasing the profit of the certifier), a profit maximizing certifier has no incentive to prevent mistakes. Hence, the parameterization of costs does not affect the result.

\footnotetext{
${ }^{23}$ We assume the cost function $c_{C F}(\varepsilon)=a(1 / \varepsilon-2)$. This functional form meets the requirements from A6: costs are infinite for perfect detection, $\varepsilon=0$, and 0 for the worst detection, $\varepsilon=1 / 2$. Costs are high with $a=.1$ and low with $a=.01$.
} 
The optimal standard is also identified balancing marginal revenue and marginal cost. Increasing the standard increases the maximum possible fee that charities may be charged; it decreases, however, the number of applicants paying the fee. Because the optimal fee the certifier may charge is limited, the marginal cost of increasing the standard is always above the revenue. It is thus optimal for the for-profit certifier to set the standard as low as possible, $s=0$. That is, the certifier maximizes profit by allowing all charities to be awarded the certificate (donors still appreciate potential identification of the 'worst' charity), resulting in a pooling equilibrium. ${ }^{24}$

The optimal price the certifier must charge in the pooling equilibrium would be $1 / 4$ according to the ICCs [4]. However, this price was determined under the assumption that the certifier examines the charities that apply and that the charity at the separating point is assessed correctly with probability $1 / 2$. In a pooling equilibrium, the certifier awards the certificate to all organizations that apply, i.e., the probability of being awarded the certificate is 1 if the charity paid the fee (the internal costs are 0 at $s=0$ ). Thus, the maximum fee a certifier may charge in this equilibrium is $E[t]$, the expected donation of a certified charity.

In summary, the profit-maximizing certifier chooses the maximum possible fee, $P=P^{*}(s)$ $=1 / 2$, the minimum possible standard, $s=0$, and does not invest in detection, $\varepsilon=1 / 2$. This result is not affected by various cost parameterizations.

B.) Nonprofit certifier-'Money to Africa' maximization

The certifier maximizes welfare:

\footnotetext{
${ }^{24}$ We analyzed also a case with a different giving function, which allowed infinite giving to the best charity (unlimited); in that case it is optimal to set standard as high as possible, $s=1$, because the optimal fee, $P^{*}$, in this case converges to infinity as the standard converges to 1 (due to the accumulation of all giving in one charity), guaranteeing an unlimited income to the certifier.
} 


$$
\begin{aligned}
& \operatorname{Max}_{\mathrm{P}, \mathrm{s}, \varepsilon} \mathrm{D}_{A}\left[(2 E[t \mid t>s]-1) \frac{f(t>s \mid c)}{f_{C}}+(2 E[t \mid T<t<s]-1) \frac{f(t<s \mid c)}{f_{C}}\right] \\
& f(t>s \mid c)=(1-s)\left(\frac{1}{2}+\frac{(1-s)}{4 \varepsilon}\right) \quad \text { if } s+\varepsilon>1 \\
& f(t>s \mid c)=\left(1-s-\frac{\varepsilon}{4}\right) \quad \text { if } s+\varepsilon<1 \\
& f(t<s \mid c)=(s-T)\left(\frac{1}{2}+\frac{(T-s)}{4 \varepsilon}\right) \\
& D_{A}=E[t \mid t>s] f_{\mathrm{C}}-P f_{C} \\
& \text { s.t. } B C: P(1-T) \geq c_{C F}(\varepsilon)
\end{aligned}
$$

The welfare is calculated as money that reaches those in need, $t$ (A2), less the costs incurred, defined as $1-t .^{25}$ These are multiplied by the relative proportions, denoted $f(t>s \mid$ $c$ ) and $f(t<S \mid c)$, respectively, of certified charities of quality above or below the standard. The resulting sum is multiplied by $D_{\mathrm{A}}$ which denotes aggregate giving less aggregate fees spent on certification.

In the current definition of welfare we do not explicitly model the certifier's reputational losses caused by bad charities receiving the certificate. The impact of bad charities on welfare is symmetric to that of good ones: they both affect welfare through their average quality, i.e., bad charities do not have an explicit negative effect on welfare, but their contribution is below that of good charities. Note that we could easily account for more significant reputational losses by using a suitably defined parameter on the term denoting the contribution of bad charities. The current definition represents a benchmark case in which the highest number of bad charities is allowed to apply.

Similar to the preceding case, the certifier maximizes the welfare function choosing all three variables $s, P$, and $\varepsilon$ simultaneously; we discuss the individual choices in turn.

\footnotetext{
${ }^{25}$ We assume the quality of charities $t$ to be uniformly distributed over $[0,1]$ (A2). $1-t$, our measure of costs, represents the complement of the quality $t$ to the maximum possible quality, 1 .
} 
The average welfare-maximizing standard is 1 ; the aggregate giving-maximizing standard is $1 / 2$ (an increase in donations due to an increased standard is equal to the decrease due to a lower number of observed certified charities). The effect on aggregate donations outweighs the impact on the average welfare reached, i.e., the optimal standard is $1 / 2$. The equilibrium standard is shifted slightly from this value (the result with perfect detection and separation at $s$ ) by the choice of the other two variables.

The optimal fee for certification balances the marginal revenue and marginal cost of increasing the fee. An increase in the fee represents a direct decrease in welfare because the fee decreases the amount charities may spend on their charitable mission. If this effect prevailed, the optimal fee would be the lowest possible. On the other hand, an increase in the fee prevents bad charities from applying for certification and being awarded the certificate by mistake which would decrease the average welfare. In addition, an increase in the fee means additional income for the certifier, which can (and must) be spent on the detection technology. Welfare is maximized when the number of bad charities being awarded the certificate is zero. (It makes no difference if they did not apply for it, or were rejected based on the evaluation.) The incentive to keep bad charities out outweighs the positive effect of decreasing the aggregate fees, thus the welfare-maximizing certifier chooses a fee high enough to make it attractive only for a small fraction of bad charities to apply. It is optimal to decrease the fee to allow some bad charities to apply and identify them using the detection technology because these applicants pay the fee (and increase revenue) but they do not decrease the average welfare as they do not receive the certificates in the end.

An improvement in the detection technology increases welfare by shifting the proportion of certified organizations towards those above the standard (good charities are correctly assessed to be above $s$, bad charities are correctly assessed to be below, and are not awarded the certificate). Also, a better detection technology makes it more difficult for bad charities to apply for the certificate in the first place by decreasing their expected donation (decreasing the probability that they will obtain the certificate). The detection technology is 
funded from the fees received for certification. A welfare-maximizing certifier spends all his revenue on the detection technology as detection has a positive effect on the welfare, and also, there is no alternative use of the revenue.

In summary, the welfare-maximizing certifier confronted with a high-cost technology, $a=$ .1 , sets the fee below the one leading to separation at $s, P=.09<P^{*}(s)=.16$. Separation, thus, occurs below $s, T=.56<s=.60$. The certifier is able to afford a technology of quality $\varepsilon=.41$. With a low-cost technology, $a=.01$, the optimal choice of fee is similar, $P=.07<$ $P^{*}(s)=.14$. Separation now occurs at a point closer to the standard, $T=.51<s=.54,{ }^{26}$ and the affordable detection technology is significantly better, $\varepsilon=.18 .^{27}$

With both high-cost and low-cost technologies a welfare-maximizing certifier allows bad charities to apply for certification. He maintains the quality of certified charities using a combination of fee and detection. The trade-off between these two tools depends on their relative costs: With the cheap technology the certifier prefers to decrease the fee, as the lower fee still allows him to buy technology good enough to keep a reasonable number of bad charities out.

B.) Numerical summary of results, welfare comparison

\footnotetext{
${ }^{26}$ This result seems to be counterintuitive: with better technology the certifier shall be able to rely more heavily on detection technology, thus the number of bad charities applying shall be higher, however, most of them shall be rejected after the evaluation. However, it is necessary to keep in mind that an improvement in the technology affects also the willingness of the bad charities to apply, as it decreases their probability of being awarded the certificate, which is exactly what happens in the case with low cost technology.
} 
Table 1: Summary of numerical results

\begin{tabular}{|c|c|c|c|}
\hline & Profit-maximization & \multicolumn{2}{|c|}{ Money to Africa } \\
\hline$a$ & $.1, .01$ & .1 & .01 \\
\hline$P / P^{*}$ & $1 / 2 / 1 / 2$ & $.09 / .16$ & $.07 / .14$ \\
\hline$s / T$ & $0 / 0$ & $.56 / .60$ & $.51 / .54$ \\
\hline$\varepsilon$ & $1 / 2$ & .41 & .18 \\
\hline
\end{tabular}

Table 1 summarizes the results obtained in Sections 4.4.A and 4.4.B. We need to keep in mind that the two cases analyzed represent two extremes of the possible optimization functions a certifier may have. Most likely, certifiers maximize a convex combination of societal welfare and their profit, the relative weights of these components being a function of the legal form (nonprofits are assumed to care little, or not at all, about their profits), and other factors (e.g., enforcement of the non-distribution constraint, which could enable the existence of for-profits in disguise). Thus, any results in between the two polar cases analyzed may be observed in reality.

The profit-maximizing certifier chooses a pooling equilibrium, setting $s$ to 0 , and gives the certificate to all the charities in the market. The welfare-maximizing certifier chooses a separating equilibrium, setting $s$ slightly above $1 / 2$, the point where aggregate donationsthe main driving force of welfare-reach their maximum. $(s=1 / 2$ would be chosen if a perfect detection technology were available, for imperfect detection and costly technology the certifier has to set the standard higher to compensate for the lower number of the certified charities observed by donors.) The profit-maximizing certifier does not care about maximizing aggregate donations; he cares about the expected donations of individual charities as these determine the maximum fee he may charge for certification.

\footnotetext{
${ }^{27}$ In the alternative case with the expected donation going to infinity, the choices of a welfare maximizing certifier are qualitatively similar to those obtained in this case, but, the standards in both cases are higher (as the optimal level is 1), leading to higher fees charged, and, consequently, better technologies.
} 
In contrast to the profit-maximizing certifier, the welfare-maximizing certifier reduces the fee, maintaining the quality of certified charities using the available detection technology. At $T=s$, the number of bad charities having the certificate is 0 , and welfare is maximized. However, reaching this goal using the fee only is very 'welfare costly'; the certifier needs to charge fees below the one ensuring this optimum and use technology to maintain high quality. Obviously, if technology is cheap, the certifier relies relatively more on detection rather than fees.

The result that welfare is highest with a nonprofit certifier is a direct consequence of the modeling approach we have chosen. However, the effect of a shift from a profitmaximizing certifier towards a welfare-maximizing certifier is still informative. In addition, our modeling approach allows us to shed light on the relative welfare production of certifiers (profit-maximizing and welfare-maximizing) on the one hand and the case of no certification on the other.

Comparing the case of no certification with that of a profit-maximizing certifier is inconclusive, as welfare as defined so far is zero in both cases. However, we can relax the welfare definition slightly and compare the amounts of donations that reach those in need (public benefit). Then, no certification is preferred to a profit-maximizing certifier: In Section 4.4.A we showed that a profit-maximizing certifier chooses a pooling equilibrium with all charities receiving a certificate. Consequently, the average quality of charities with a certificate and receiving donations is the same as if there was no certification at all. But, in the case with certification, the certifier collects most of the donations received by the charities, leaving very little to be spent on the charitable purpose itself. This result follows from the behavior (and beliefs) of donors who trust that the certifier identifies the 'good' charities even if he sets the standard to $0{ }^{28}$ This result is similar to those from Lizzeri (1999) and Peyrache and Quesada (2002). If certification was not available, the average quality would remain the same, but the charities would be able to spend all the received 
donations on the charitable goal (depending on their efficiency). Thus, the market with a profit-maximizing certifier is the worst option in terms of welfare and public benefit.

Yet, it is necessary to ask whether it is possible for a nonprofit certifier to emerge in the fundraising market, and if so, whether his optimization function would be similar to the one that we analyzed. ${ }^{29}$ We claim that the answer is yes to both these questions. Whether a nonprofit certifier is likely to emerge requires an analysis of the motivation of potential entrepreneurs to start a certification agency. Analogous to the model of sequential fundraising proffered by Vesterlund (2003), we suggest that in markets where there is no big donor who would be able to signal the quality of a charity by giving a big seed donation, one of the small donors may decide to spend her donation on starting a certification agency to assess the quality of charities that provide the public good she is interested in. The optimization function of such an entrepreneur would be very similar to the welfare function suggested above. ${ }^{30}$

\section{Conclusion: Future work and policy implications}

We have built a model which illustrates how, and under what conditions, an independent certifier might mitigate the principal-agent problem in fundraising, or the fundraising problem. In contrast to previous literature, we studied both for- and non-profit organizational forms of the certifier. Our results (in particular, those assuming the 'Money to Africa' welfare function) seem to rationalize the stylized facts of certification systems that we have identified.

Specifically, certification agencies that deal with variants of the fundraising problem that we observe in various Western European countries and the U.S.A. and Canada (and that are

\footnotetext{
${ }^{28}$ Specifically, they believe that even if the standard is 0 , they prefer to give to those with the certificate, i.e., they believe that those without the certificate (out of equilibrium belief) are of quality 0 , thus, would give them 0 .

${ }^{29} \mathrm{We}$ analyze this question in more detail in a related work (in progress).

${ }^{30} \mathrm{We}$ are grateful for this remark to R. Steinberg.
} 
discussed in more detail in Ortmann, Svitkova, and Krnacova, 2005) are all nonprofits, impose relatively high standards on applicants, and indeed certify only a fraction of the (potential) applicants.

Some avenues that we could take in future work are self-evident:

First, although relatively simple, our model is not analytically trackable. It would be desirable to build a model that could be tracked analytically (although that might come at the cost of having to simplify the model even further).

Second, given that we were not able to solve the model analytically, we had to make do with functional specifications that are constrained only by our intuition of what the appropriate functional specifications are (e.g., the cost functions or the detection technology). Obviously, further testing of the robustness of these specifications would be desirable. $^{31}$

Third, there is very little work out there (the notable exception being Bekkers, 2003) that would allow us to calibrate our model and hence rationalize our choice of particular functional specifications. For example, the Austrian model of certification on the one hand and the Dutch and German models of certification on the other hand differ in a key aspect: the former relies heavily on external 'investigators' (using, however, its quality assessment instrument) while the latter use internal investigators. This difference is very likely to affect the interplay of detection probability and welfare effects of bad types being, mistakenly, certified as good types. Unfortunately, we have no inkling about this relationship (although we suspect that the Austrian model is tempting fate).

Fourth, we solved the model with a monopolistic certifier only. Some of the related papers (e.g., Lizzeri, 1999; Peyrache and Quesada, 2002) suggest that the market may benefit from competition among certifiers (but see Strausz, 2005). While all European fundraising 
industries have one certification agency only, there are competing certification agencies entering the industry in the U.S.A. recently, suggesting that an analysis of the (dis)advantages of competition in the nonprofit sector is wanting.

Fifth, we have assumed (A10) that the certifier is honest and does not misrepresent the standard or the quality of the certified organizations (for, say, for-profit maximizing reasons). This is, quite likely, an heroic assumption, especially in transition and developing countries where concepts of accountability and transparency, or reputational enforcement, often seem rather alien. A certifier, in other words, might have an incentive to cheat (as self-regulatory systems are prone to do, e.g., Nunez, 2001, 2002) and it is important to understand what exactly these incentives are and how they could be undermined.

Sixth, and relatedly, there is the question of whether one should force the certification agency to make ends meet, or whether it should be supported by state subsidies. This, too, ought to be modeled.

What are the policy implications of our model?

Clearly, certification systems are viable quality assurance mechanisms in transition and developing countries. But getting the particular realization of such a system right is an endeavor that takes reflection. Our results suggest an important requirement, the certification agency ought to be organized as a non-profit organization. ${ }^{32}$ Moreover, it needs to be both accountable and transparent. Our results so far also suggest that, to the extent that they allow for the choice of a better detection technology, public subsidies for a certification system might be desirable.

\footnotetext{
${ }^{31}$ We started with preliminary tests of robustness of the internal costs function specification, which suggest that there exists a family of functions with costs decreasing in type and increasing in standard (such as $c(t, s)$ $=(1-t) s^{2}$, or $\left.c(t, s)=(1-t) s / t\right)$ that lead to similar qualitative results as those obtained in the paper.

${ }^{32} \mathrm{We}$ understand well that nonprofits are often afflicted with their own sets of incentive problems (e.g., Ortmann and Schlesinger, 2003).
} 
To repeat, our model addresses a gap in the existing literature on certification. Informed to a certain extent by the existing certification agencies in fundraising industries in several European countries, we built a model that shows the importance of the nonprofit legal form of the agency. It is necessary to realize that even though the model has been built for the fundraising industry in the first place, the results are applicable in other industries facing the asymmetric information problem. 
References

Akerlof, G. A. (1970), “The Market for Lemons", Quarterly Journal of Economics, 84, pp. 488-500.

Andreoni, J. (1990), "Impure Altruism and Donations to Public Goods: A Theory of WarmGlow Giving", Economic Journal, v.100, June 1990, pp. 464 - 477.

Bekkers, R. (2003), "Trust, Accreditation, and Philanthropy in the Netherlands", Nonprofit and Voluntary Sector Quarterly, 32 (4), pp. 596-615.

Biglaiser, G. (1993), "Middlemen as Experts", The RAND Journal of Economics, 24 (2), pp. 212-223.

Biglaiser, G., Friedman, J. W. (1994), "Middlemen as Guarantors of Quality", International Journal of Industrial Organization, 12, pp. 509-531.

Brhlikova, P. (2004), "The Nonprofit Sector in the Czech Republic", CERGE-EI Discussion Paper No. 2004-128, May 2004.

Bullain, N., Marshall, M. (2005), "Report on the December 2004 Budapest Workshop on Good Governance and Accountability in the Non-profit Sector in the Visegrad Countries", March 2005.

Froelich, K. A., Knoepfle, T. W., Pollak, T. H. (2000), "Financial Measures in Nonprofit Organization Research: Comparing IRS 990 Return and Audited Financial Statement Data", Nonprofit and Voluntary Sector Quarterly, 29 (2), pp. 232-254.

Giving USA (2004), www.aafrc.org.

Gibelman, M., Gelman, S.R. (2004), “A Loss of Credibility: Patterns of Wrongdoing Among Nongovernmental Organizations". Voluntas 15 (5), pp. 355-381.

Glazer, A., Konrad, K. A. (1996), "A Signaling Explanation for Charity", The American Economic Review, 86(4), pp. 1019-1028.

Gronbjerg, K. A. (1997), "Transaction Costs in Social Service Contracting: Lessons From the USA," in Perri 6 and Jeremy Kendall (ed.), The Contract Culture in Public Services, Brookfield VT, Ashgate Publishing.

Guet, I. H. (2002), Monitoring Fundraising, A Comparative Survey of ICFO Members and Their Countries, Berlin: ICFO.

Handy, F. (1995), "Reputation as Collateral: An Economic Analysis of the Role of Trustees of Nonprofits", Nonprofit and Voluntary Sector Quarterly, 24(4), pp. 293-305 
Hansmann, H. B. (1980), “The role of nonprofit enterprise”, Yale Law Journal, 89, pp. 835901.

Harbaugh, W. T. (1998a), "The Prestige Motive for Making Charitable Transfers", American Economic Review, Papers and Proceedings, 88(2), pp. 277-282.

Harbaugh, W. T. (1998b), "What Do Donations Buy? A Model of Philanthropy Based on Prestige and Warm Glow", Journal of Public Economics, 67(2), pp. 269-284.

Lizzeri, A. (1999), "Information Revelation and Certification Intermediaries", The RAND Journal of Economics, 30 (2), pp. 214-231.

Nunez, J. (2001), “A Model of Self Regulation”, Economics Letters, 74, 91-97.

Nunez, J. (2002), “Corruption, Impunity, and Cover-up in Self Regulation”, manuscript.

Ortmann, A., Schlesinger, M. (2003), "Trust, Repute, and the Role of Nonprofit Enterprise". in The Study of the Nonprofit Enterprise (eds: Avner Ben-Ner and H. K. Anheier), pp. 77-114, Kluwer Academic/Plenum Publishers.

Ortmann, A., Svitkova, K., Krnacova, A. (2005), "Certification as a Viable Quality Assurance Mechanism in Transition Economies: Evidence, Theory, and Open Questions", CERGE-EI Discussion Paper No. 2005-139, March 2005.

Panel on the Nonprofit Sector (2005), "Interim Report", Available at www.nonprofitpanel.org/interim.

Peyrache, E., Quesada L. (2002), "Monopoly Intermediary and Information Transmission", EconWPA, April 2002.

Peyrache, E., Quesada L. (2004), “Strategic Certification”, manuscript.

Rose-Ackerman, S. (1980), "United Charities: An Economic Analysis", Public Policy, 28(3), pp. 323-348

Salamon, L. M., Anheier, H.K. and associates (1999), "Global Civil Society: Dimensions of the Nonprofit Sector”, Baltimore, MD: Johns Hopkins Center for Civil Society Studies, 1999.

Spence, M. (1973), “Job Market Signaling”, The Quarterly Journal of Economics, 87(3), pp. 355-374.

Strausz, R. (2005), "Honest Certification and the Threat of Capture", International Journal of Industrial Organization, 23(1-2), pp. 45-62. 
Svitkova, K. (2004), "The Evolution of the Third Sector in Slovakia", CERGE-EI Discussion Paper No. 2004-122.

Vesterlund, L. (2003), “The Informational Value of Sequential Fundraising”, Journal of Public Economics, 87, pp. 627-657. 
Individual researchers, as well as the on-line and printed versions of the CERGE-EI Working Papers (including their dissemination) were supported from the following institutional grants:

- Center of Advanced Political Economy Research [Centrum pro pokročilá politicko-ekonomická studia], No. LC542, (2005-2009),

- Economic Aspects of EU and EMU Entry [Ekonomické aspekty vstupu do Evropské unie a Evropské měnové unie], No. AVOZ70850503, (2005-2010);

- Economic Impact of European Integration on the Czech Republic [Ekonomické dopady evropské integrace na ČR], No. MSM0021620846, (2005-2011);

Specific research support and/or other grants the researchers/publications benefited from are acknowledged at the beginning of the Paper.

(c) Katarína Svítková, Andreas Ortmann, 2006

All rights reserved. No part of this publication may be reproduced, stored in a retrieval system or transmitted in any form or by any means, electronic, mechanical or photocopying, recording, or otherwise without the prior permission of the publisher.

Published by

Charles University in Prague, Center for Economic Research and Graduate Education (CERGE) and

Economics Institute (EI), Academy of Sciences of the Czech Republic

CERGE-El, Politických vězňů 7, 11121 Prague 1, tel.: +420 224005 153, Czech Republic.

Printed by CERGE-EI, Prague

Subscription: CERGE-EI homepage: http://www.cerge-ei.cz

Editors: Directors of CERGE and EI

Managing editors: Deputy Directors for Research of CERGE and EI

ISSN 1211-3298

ISBN 80-7343-083-5 (Univerzita Karlova v Praze, CERGE)

ISBN 80-7344-072-5 (Národohospodářský ústav AV ČR, Praha) 
CERGE-EI

P.O.BOX 882

Politických vězňů 7

11121 Praha 1

Czech Republic http://www.cerge-ei.cz 